\title{
Mekanisme Hipotetikal Efek Konsumsi Ikan Menurunkan Resiko Serangan Jantung
}

(Hypothetic Mechanisms of Fish Consumption Effects Reduce Risk of Heart Attack)

I Dewa Ayu Susilawati

Bagian Biomedik Fakultas Kedokteran Gigi Universitas Jember

\begin{abstract}
Abstrak
Potensi maritim Indonesia terkait ilmu kesehatan belum banyak dieksplorasi. Studi di Indonesia tentang potensi sumber daya laut untuk meningkatkan kesehatan masih sangat sedikit. Artikel ini merangkum laporan dari majalah dan jurnal di luar negeri tentang konsumsi ikan yang potensial menurunkan risiko serangan jantung. Diduga potensi ini terkait dengan kandungan asam lemak omega-3 (n-3) tak jenuh pada ikan. Laporan pengamatan, studi klinis, hewan dan in vitro telah menunjukkan manfaat omega-3 mencegah dan mengobati penyakit kardiovaskular. Meskipun mekanismenya tidak jelas, tetapi telah ditunjukkan bahwa efek perlindungan jantung dari asam lemak n-3 dapat disebabkan oleh perannya yang mempengaruhi efek biologis pada metabolisme lipid dan lipoprotein, fungsi trombosit, distribusi kolesterol arteri, fungsi vaskular dan respons inflamasi.
\end{abstract}

Kata kunci : asam lemak n-3, ikan, lipid, radang, serangan jantung

\section{Abstract}

Potential maritime Indonesia related health science has not been widely explored. Studies in Indonesia about the potential of marine resources to improve health are still very little. This article summarized a reports from magazines and journals in foreign countries about the potential fish consumption lowers the risk of heart attack. Allegedly this potential is related to the content of unsaturated fatty acids omega-3 ( $n-3)$ on fish. The report of observations, clinical animal and in vitro studies have demonstrated the benefits of omega-3 prevent and treat cardiovascular disease. Although the mechanism is not clear, but it has been shown that the cardioprotection effect of $n-3$ fatty acids may be caused by its role influencing biological effects on lipid and lipoprotein metabolism, platelet function, arterial cholesterol distribution, vascular function and inflammatory response.

Keywords: fish, heart attack, n-3 fatty acid, lipid, inflammation

Korespondensi (Correspondence) : I Dewa Ayu Susilawati, Bagian Biomedik Fakultas Kedokteran Gigi, Universitas Jember, Jl Kalimantan 37 Jember, E-mail: dewasusi@unej.ac.id

Indonesia sebagai Negara maritim memiliki kekayaan sumber daya laut yang luar biasa, sayangnya potensi ini belum banyak dieksplorasi dan dimanfaatkan secara layak untuk meningkatkan kesejahteraan masyarakat. Salah satu potensi sumber daya laut adalah untuk meningkatkan derajad kesehatan, namun sampai saat ini, hal ini belum mendapat perhatian yang signifikan dari pemerintah maupun berbagai pihak, terbukti dari sangat minimnya kajian ataupun aktivitas penelitian terkait hal ini. Paper ini bertujuan mengungkap perpektif penting dari sumber daya laut Indonesia yang selama ini terabaikan, yakni potensinya untuk menurunkan resiko penyakit kardiovaskuler, khususnya serangan jantung.

Serangan jantung merupakan masalah kesehatan utama di Indonesia karena menjadi penyebab kematian nomer satu pada individu di atas 40 tahun. Patomekanisme serta faktor-faktor yang memicu serangan jantung sampai saat ini belum sepenuhnya diketahui, hal ini berdampak pada sulitnya mengantisipasi munculnya serangan jantung, sehingga masih banyak ditemui kasus kematian mendadak karena sindrom ini. Belum jelasnya faktorfaktor resiko yang dapat memicu serangan jantung juga berdampak pada mortalitas penyakit ini. WHO memperkirakan, tiap tahun 17 juta penduduk meninggal karena penyakit ini ( $\pm 40 \%$ dari total kematian di dunia), separuh lebih dari negara berkembang.1, 2 Tahun 2020 diprediksi penyakit kardiovaskuler akan menjadi penyebab kematian utama di seluruh dunia. ${ }^{3} \mathrm{Di}$ Indonesia, menurut Survei Kesehatan Rumah Tangga Departemen Kesehatan, sejak tahun 1995 penyakit kardiovaskuler tercatat sebagai penyebab kematian nomer satu pada komunitas di atas 40 tahun. ${ }^{4}$

Tiga dekade akhir ini, penelitianpenelitian di luar negeri melaporkan potensi mengkonsumsi ikan untuk menurunkan resiko serangan jantung. Hal ini dipicu oleh hasil penelitian yang dilakukan pada orang eskimo yang menunjukkan rendahnya resiko serangan jantung, diduga ini karena kebiasaan mereka mengkonsumsi ikan. Potensi ikan tersebut diduga terkait dengan kandungan asam lemak tak jenuh n-3 yang banyak ditemui pada ikan. Berbagai suplemen asam lemak n-3 diproduksi dan diteliti, tetapi sejauh ini hasil penelitian masih kontroversial, karena bukti menunjukkan bahwa mengkonsumsi suplemen asam lemak n-3 hanya sedikit mengurangi resiko serangan jantung dibanding mengkonsumsi ikan secara langsung. Hal ini memunculkan dugaan adanya interaksi antara komponen- 
komponen pada ikan, misalnya dengan asam lemak omega-6, protein, dll. Beberapa mekanisme yang diduga menjelaskan peran konsumsi ikan menurunkan resiko serangan jantung adalah perannya mempengaruhi efek biologik pada metabolisme lipid dan lipoprotein, fungsi platelet, fungsi vaskuler dan respons inflamasi. Paper ini bertujuan merangkum laporan-laporan dari majalah/jurnal tentang potensi konsumsi ikan untuk menurunkan resiko serangan jantung

\section{KAJIAN PUSTAKA}

\section{Pengertian Serangan Jantung}

Serangan jantung merupakan manifestasi sindrom koroner akut lacute coronary syndrome), disebut juga infark miokardial akut, karena terjadi kematian otot jantung yang disebabkan oleh berhentinya aliran darah karena penyumbatan secara tiba-tiba arteri koroner oleh trombus. Arteri koroner adalah pembuluh darah yang memasok darah dan oksigen ke sel-sel otot jantung. Penyumbatan pada arteri koroner mengurangi pasokan darah dan oksigen menuju otot jantung (iskemia) mengakibatkan injuri pada otot jantung dan menghasilkan manifestasi klinis nyeri dada (angina pectoris). Jika aliran darah ke jantung tidak pulih dalam waktu 20 - 40 menit, bisa mengakibatkan kematian otot jantung yang tidak dapat pulih (irreversible). Kematian otot jantung secara komplit terjadi antara 6-8 jam. Sel otot jantung yang mati akan digantikan oleh jaringan parut. Jadi serangan jantung merupakan manifestasi klinis akut penyakit kardiovaskuler yang dapat ditandai dengan angina pektoris (nyeri dada), infark miokardial akut atau bahkan kematian mendadak.5.6

\section{Patomekanisme Serangan Jantung}

Serangan jantung sering terjadi berkaitan dengan aterosklerosis, suatu penyakit pada arteri koroner yang ditandai oleh pengerasan dinding pembuluh koroner, karena timbulnya plak aterosklerotik (ateroma, dungkul pada dinding arteri). Struktur bagian dalam (inti) ateroma mengandung material timbunan lemak terutama kolesterol. Timbunan kolesterol menyebabkan pengerasan dinding arteri dan penyempitan lumen arteri (stenosis). Permukaan plak aterosklerotik diselubungi oleh lapisan pelindung yang terutama tersusun oleh kolagen disebut fibrous caps. Apabila plak ateroma pecah, menyebabkan fibrous cap robek (ruptur), maka akan terbentuk trombus (bekuan darah). Bila trombus mengakibatkan oklusi pembuluh darah koroner maka aliran darah ke jantung akan terganggu. Gangguan aliran darah ini dapat menyebabkan iskhemia dan kematian jaringan jantung. Keadaan ini menimbulkan manifestasi serangan jantung, dan ini dapat berakibat fatal menyebabkan kematian.6-9

Aterosklerosis tidak terjadi secara mendadak, melainkan melalui sejumlah tahapan. Pada tahap awal, di daerah subintima ditemukan sekelompok sel yang dalam sitoplasmanya terlihat gelembunggelembung mirip busa sabun yang disebut foam cell. Foam cell ini berasal dari makrofag dan gelembung mirip busa sabun tersebut berisi ester kolesterol. Lama kelamaan foam cell dapat menumpuk sehingga mendesak endothelium. Secara makroskopik terlihat dinding arteri yang sedikit menonjol ke arah lumen. Selanjutnya, di samping foam cell terlihat pula tumpukan lemak ekstrasel yang terjadi karena foam cell yang nekrosis. Di dalam intima juga dijumpai limfosit, sel-sel otot polos dan serabut-serabut kolagen. Secara makroskopis terlihat sebagai dungkul (ateroma) yang menonjol ke arah lumen.7

Aterosklerosis adalah penyakit yang sangat kompleks, sejauh ini yang diketahui adalah faktor resikonya yang bersifat multifaktorial, antara lain dislipidemia, hipertensi, merokok, diabetes mellitus, obesitas dan inaktivasi. Kemudian ditambah dengan faktor genetik, ras, stress, asam urat, agregasi trombosit, fibrinogen, penyalahgunaan alkohol dan pengaruh radikal bebas atau reactive oxygen species (ROS). Akan tetapi, pada kenyataannya, faktor-faktor resiko tersebut tidak dapat menjelaskan secara menyeluruh patogenesis dan perkembangan aterosklerosis, dan hanya berkaitan dengan sekitar 50\% dari kasus-kasus kardiovaskuler. Akhir-akhir ini banyak dilaporkan kasus kematian mendadak pada penderita aterosklerotik usia muda di bawah usia 40 tahun pada waktu sedang melakukan aktivitas, karena terjadinya penyumbatan pembuluh darah jantung. Pada penderita tersebut tidak didapatkan faktor resiko konvensional seperti hiperkolesterol, hipertensi atau diabetes melitus.

Dekade akhir ini berkembang paradigma baru yang menyebutkan bahwa respons inflamasi terhadap infeksi mikroorganisme berperan penting pada pembentukan dan perkembangan aterosklerosis. Hipotesis yang mendukung peranan infeksi pada patogenesis aterosklerosis, antara lain didasarkan oleh, ditemukannya berbagai mikroorganisme patogen (Chlamydia pneumoniae, Herpes simplex virus (HSP), Helicobacter pylori, Cytomegalovirus) pada lesi aterosklerotik.10-12 Infeksi mikroorganisme juga dilaporkan dapat menyebabkan lisisnya fibrous cap sehingga mengakibatkan rupturnya plak

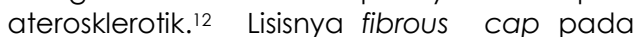
plak ateroma dapat terjadi karena aktivitas matrix metallo proteinase (MMPs). Berbagai mikroorganisme $(P$. gingivalis, $S$. mutans, $S$. sanguis) dapat menghasilkan protease yang dapat mengaktifkan MMPs melalui mekanisme proteolitik ikatan peptida pada tempat tertentu. ${ }^{13}$ MMPs yang aktif menyebabkan lisis serabut kolagen penyusun fibrous cap pada plak ateroma sehingga menjadi tipis dan mudah ruptur. 

Mekanisme Proteksi Konsumsi lkan pada
Serangan Jantung

Mekanisme yang pasti bagaimana mengkonsumsi ikan menurunkan insidensi serangan jantung belum diketahui dengan jelas, tetapi dugaan kuat adalah karena peran asam lemak n-3 mempengaruhi prosesproses pada perkembangan aterosklerosis dan pembentukan trombus, seperti pada metabolisme lipid dan lipoprotein, distribusi kolesterol arterial, fungsi vaskuler dan platelet, serta respons inflamasi. Secara molekuler, dapat dijelaskan, bahwa efek asam lemak n3 melibatkan mekanisme interaksi multipel pada molekul atau enzim terkait jalur signaling selular yang memodulasi metabolisme eikosanoat, respons imun yang menyebabkan perubahan respons inflamasi, inkorporasi asam lemak n-3 ke dalam fosfolipid membran dan efek langsung pada ekspresi gen. Misalnya asam lemak n-3 mempengaruhi ekspresi beberapa protein kunci yang berperan memodulasi gen yang berperan pada metabolisme lipid, inflamasi, proliferasi otot polos, gen yang berperan penting pada prevensi dan pengobatan penyakit kardiovaskuler dan aterosklerosis. ${ }^{14-15}$

\section{Asam Lemak n-3}

Asam lemak $n-3$ sering disebut sebagai asam lemak $\omega-3$ atav omega-3, adalah famili dari asam lemak tak jenuh (unsaturated fatty acids) yang memiliki ikatan karbon-karbon rangkap pada posisi ketiga dari ujung metil (posisi n-3). Berbagai jenis asam lemak $n-3$ meliputi, asam alfa linoleat(a-linolenic acid, ALA), asam eikosapentanoat (eicosapentaenoic acid, EPA), dan asam dokosaheksaenoat (docosahexaenoic acid, DHA), semuanya merupakan asam lemak jenuh dengan ikatan rangkap lebih dari satu (polyunsaturated). Asam lemak n-3 merupakan asam lemak esensial yang memiliki atom karbon lebih dari 20, tubuh manusia tidak dapat melakukan sintesis de novo, tetapi dapat mensintesis asam lemak rantai panjang 20 karbon (EPA) atau karbon 22 (DHA) dari asam lemak 18 karbon asam linoleat. Sumber utama asam lemak n-3 adalah ikan atau minyak ikan (gambar 1). ${ }^{18}$

\section{PEMBAHASAN}

\section{Efek Asam Lemak n-3 pada Lipid dan Lipoprotein Plasma}

Beberapa studi menunjukkan efek asam lemak n-3 pada penurunan triasil gliserol, baik pada individu normolipidemik ataupun hiperlipidemik. Berdasarkan meta-analysis, konsumsi EPA dan DHA 3-4 g/hari, selama 2 minggu menurunkan triasilgliserol plasma $25 \%$ pada individu normolipidemik dan 25-34\% pada individu hiperlipidemik. ${ }^{15}$ Balk dkk.(2006) melaporkan bahwa 0,1-5,4 g/hari EPA dan DHA menurunkan konsentrasi trigliserid puasa pada subyek sehat, penderita diabetes tipe 2 , hipertensi, dislipidemi, atau pada subyek yang terdiagnosis menderita penyakit kardiovaskuler. ${ }^{20}$

Studi efek pemberian asam lemak n-3 pada lipoprotein plasma menunjukkan efek peningkatan atau tidak adanya efek pada kolesterol HDL maupun LDL. Terdapat penelitian yang menunjukkan bahwa pemberian suplemen minyak ikan tidak memberi efek yang signifikan pada konsentrasi kolesterol HDL dan kolesterol total. ${ }^{15,20}$ Penelitian lain menyatakan, efek suplemen minyak ikan pada kenaikan kolesterol LDL disebabkan oleh peningkatan perubahan VLDL menjadi LDL. Hasil serupa juga dijumpai pada penderita diabetes tipe $2 .{ }^{21}$ Peningkatan LDL ini bisa diartikan mengurangi sifat kardioprotektif dari asam lemak n-3. Tetapi studi pada monyet menunjukkan bahwa konsumsi minyak ikan dalam jumlah besar menunjukkan bahwa LDL yang kaya asam lemak n-3 menurunkan sifat aterogenik dibanding LDL kontrol (gambar 2). Beberapa penelitian menyajikan mekanisme yang menjelaskan efek asam lemak n-3 pada homeostasis dan metabolisme lipid, yakni pada pengaturan transkripsi beberapa gen. Baik asam lemak n3 maupun n-6 dapat menghambat ekspresi gen yang terlibat pada sintesis asam lemak dan triasilgliserol. Asam lemak n-3 dan metabolitnya dapat berikatan peroxisome proliferator-activated receptor pada (PPAR) alfa dan gama untuk mempengaruhi gen yang berperan pada oksidasi beta, ketogenesis dan adipogenesis. Asam lemak didegradasi melalui jalur oksidasi beta, studi pada tikus menunjukkan bahwa suplemen minyak ikan (EPA dan atau DHA) meningkatkan oksidasi beta pada mitokondria, sehingga menurunkan substrat untuk sintesis triasil gliserol dan VLDL. Selain itu, n-3 dapat menurunkan mRNA dari regulator sterol hepatik yang mengatur gen lipogenik. Jadi n-3 berperan menurunkan lipid melalui pengaturan ekspresi gen yang mengatur oksidasi beta dan secara simultan mempengaruhi gen lipogenik. ${ }^{15}$

\section{Efek Asam Lemak n-3 pada Fungsi Platelet}

Penyebab utama munculnya sinrom koroner akut seperti serangan jantung adalah adanya ruptur plak aterosklerotik, yang kemudian memicu pembentukan trombus dan oklusi lumen arteri koroner. Asam lemak n-3 dapat menurunkan trombosis dengan cara mempengaruhi agregasi platelet dan hemostasis. Efek antitrombotik dari asam lemak n-3 terutama disebabkan oleh reduksi kompetitif perubahan asam arakidonat menjadi tromboksan $\mathrm{A}_{2}$ (promoter agregasi platelet). Peningkatan asam lemak n-3 terutama EPA menggantikan asam arakidonat pada fosfolipid membran platelet, yang menyebabkan menurunnya substrat untuk siklooksigenase untuk membentuk tromboksan $\mathrm{A}_{2}$ dan $\mathrm{PGl}_{2}$. Kandungan asam lemak $n-3$ yang lebih tinggi pada fosfolipid menyebabkan peningkatan produksi 
tromboksan 3 dan prostasiklin 3. Tromboksan 3 memiliki efek yang lebih rendah pada agregasi platelet dibanding tromboksan A2, sedang protasiklin 3 memiliki efek antiagregasi serupa dengan prostasiklin 2. Jadi secara keseluruhan, asam lemak n-3 mempengaruhi fungsi platelet melalui pengaturan jalur metabolisme eikosanoat. Selain itu, minyak ikan juga dilaporkan menurunkan faktor-faktor koagulasi yaitu faktor VII dan X. Kadar fibrinogen juga dilaporkan menurun karena efen asam lemak $n-3.15$

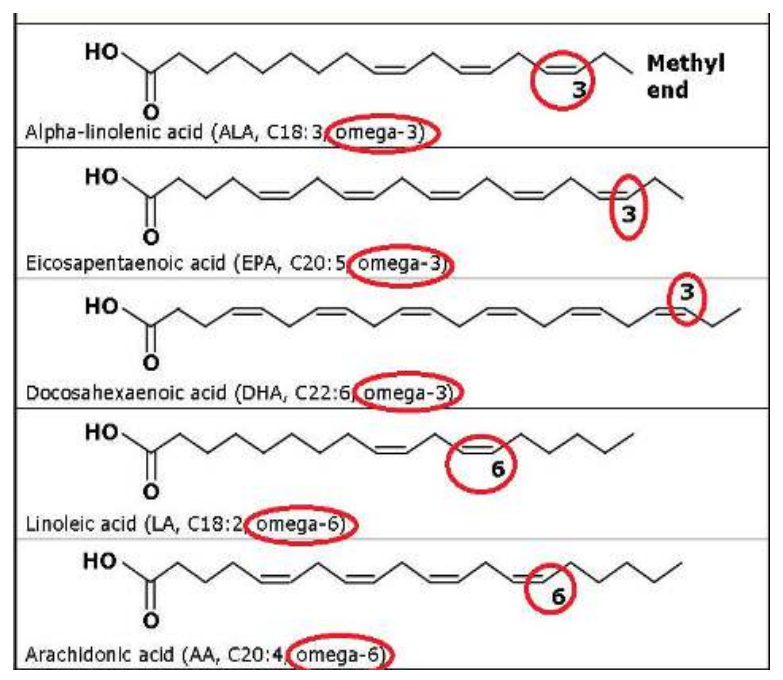

Gambar 1. Asam lemak n-3 dan n-6.19

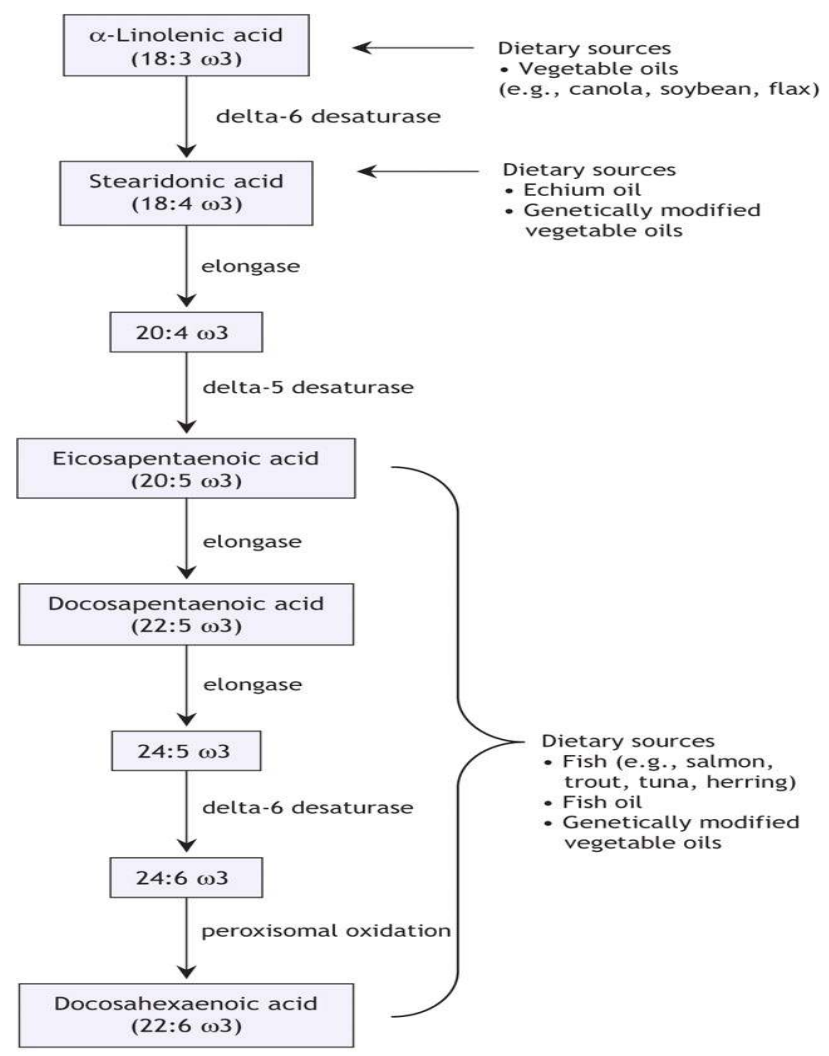

Gambar 2. Metabolisme dan sumber diet asam lemak n-3.18 


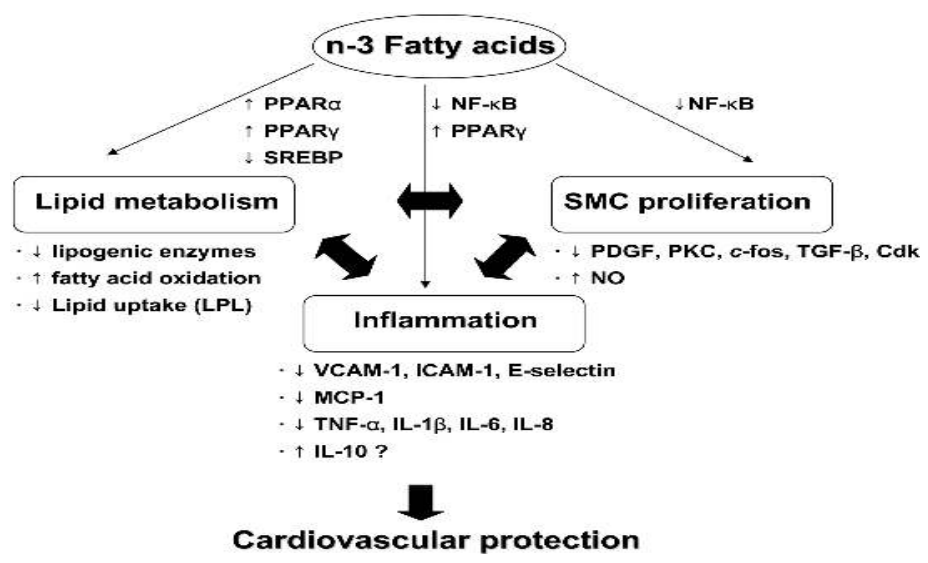

Gambar 3. Dugaan mekanisme kardioproteksi asam lemak n-3.15

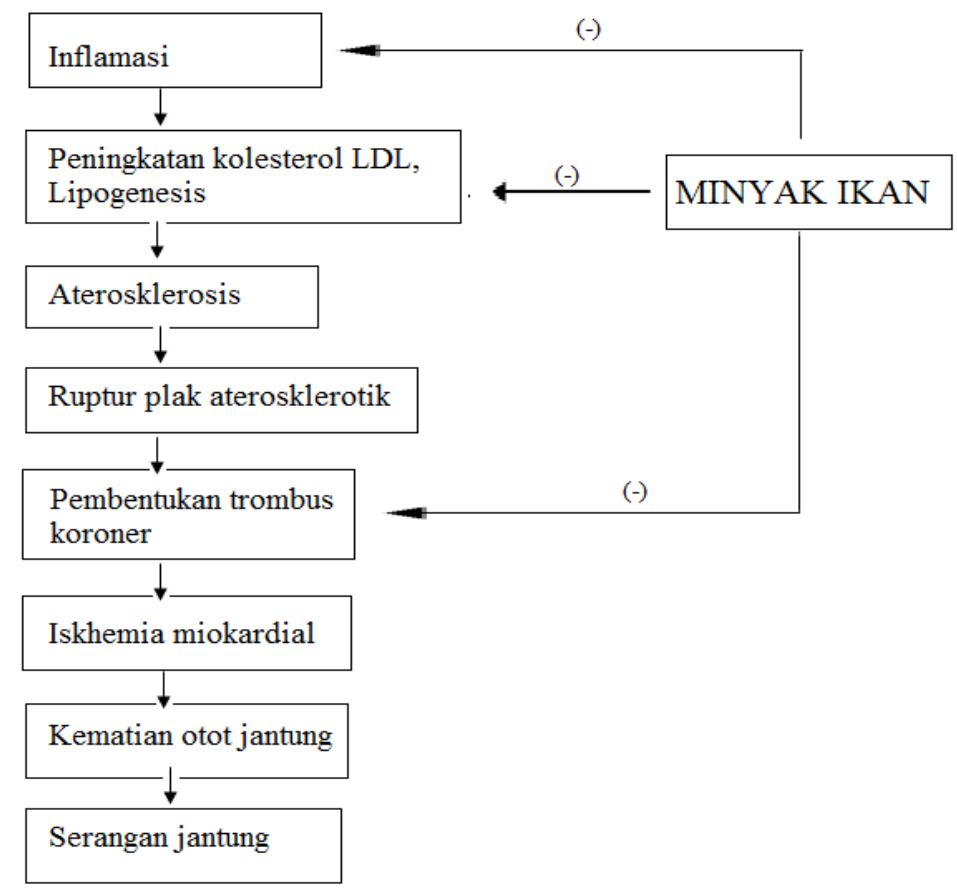

Gambar 4. Mekanisme Hipotetikal Jalur modulasi minyak ikan dalam menurunkan resiko serangan jantung. Tanda (-): menghambat

Efek Asam Lemak n-3 pada Respons Inflamasi Kini diketahui bahwa inflamasi merupakan proses kunci pada perkembangan aterosklerosis dan penyakit kardiovaskuler. Pada dinding arteri, aktivasi endotel dapat dilakukan oleh berbagai stimulus inflamatori seperti LDL teroksidasi, spesies radikal bebas, lipopolisakarida dan sitokin. Monosit sirkulasi dapat ditarik ke endoteliun oleh khemokin, berikatan dengan molekul adesi, menempel pada endotelium dan bertransmigrasi ke ruang subendotelial, yang kemudian berubah menjadi makrofag. Dalam ruang subendotelial makrofag memfagosit LDL teroksidasi dan berubah menjadi foam cell, dan lama kelamaan berkembang menjadi garis lemak (fatty streak) yang merupakan tahap awal aterosklerosis. Proliferasi otot polos vaskuler (smooth muscle cell, SMC) menyebabkan perkembangan plak dan ekspresi molekulmolekul proinflamatori, seperti monocyte chemoattractant protein 1 (MCP-1) dan molekul adesi vaskuler.

Asam lemak n-3 terutama DHA, dilaporkan dapat mereduksi adesi dan migrasi monosit dan mempengaruhi interaksi lekositendotel pada aterosklerosis dan inflamasi, mereduksi proses yang melibatkan peningkatan ekspresi molekul adesi lekosit 
atau aktivasi endotel. Terdapat laporan bahwa DHA dapat mereduksi ekspresi molekul adesi vaskuler (VCAM-1), E-selektin, molekul adesi interselular vaskuler 1 (VCAM-1), interleukin (IL) 6 dan IL-4, tumor necrosis factor alpha (TNF-a), atau endotoksin bakterial. Selain itu, DHA dan EPA dilaporkan mereduksi ekspresi TNF-a dan IL-1 $\beta$ makrofag. Pemberian asam lemak n-3, 7g/hari dalam diet menurunkan ekspresi mRNA MCP-1 pada monosit. ${ }^{17}$

Efek antiinflamasi asam lemak n-3 diduga terkait dengan kemampuannya mereduksi NFkB dan meningkatkan PPARY. Aktivasi transcription nuclear factor (NF) kB dihubungkan dengan perkembangan aterosklerosis dengan meningkatkan ekspresi gen sitokin. Aktivasi NFkB dan gen targetnya terjadi pada dinding vaskuler aterosklerotik. Faktor transkripsi yang lain, PPARY juga berperan penting dalam mengontrol inflamasi akut. Potensi antiinflamasi dan antiaterogenik dari PPARY pada monosit/makrofag, endotel dan SMC meliputi reduksi IL-1, IL-6 dan pelepasan TNF-a ke sirkulasi darah. ${ }^{15}$

Semakin banyak penelitian di luar negeri yang mendukung peran mengkonsumsi ikan atau minyak ikan (asam lemak n-3) dalam meningkatkan kesehatan kardiovaskuler (menurunkan resiko serangan jantung). Selain penyakit kardiovaskuler, masih banyak potensi lain dari sumber daya laut kita yang dapat dieksplorasi untuk meningkatkan kesejahteraan masyarakat melalui peningkatan kesehatan.

\section{DAFTAR PUSTAKA}

1. Bahorun T., Soobratte M.A., LuximonRamma V., Aruoma O.I. Free Radicals and Antioxidants in Cardiovascular Health and Disease. Internet Journal of Medical Update. 2006, 1 (2).

2. Lakhanpal P. and Rai D.K. Role of Quercetin in Cardiovascular Diseases Internet Jol. Bahorun T., Soobratte M.A., Luximon-Ramma V., Aruoma O.I. Free Radicals and Antioxidants in Cardiovascular Health and Disease. Internet Journal of Medical Update. $2006,1(2)$.

3. Lakhanpal $P$ and Rai D.K. Role of Quercetin in Cardiovascular Diseases Internet Journal of Medical Update. 2008, 3(1) : 31-49.

4. Vojdani A. A Look at Infectious Agents as a Possible Causative Factor in Cardiovascular Disease: Part I. Immunosciences Lab, Inc. Beverly Hills. 2003

5. Tjokroprawiro. "The Villian" and "The Hero" pathway in atherogenesis. Basic Course: Lipid, Calcium Metabolism, and
Bone Disease. Brawijaya University Malang. 2002.

6. Price M.J., Shah P.K. Feature: Biology of the Vulnerable Plaque: Part I. Cath Lab Diges. 2002, $10: 4$.

7. Shah P.K. Insights into Molecular Mechanism of Plaque Rupture and Thrombosis. Division of Cardiology and Atherosclerosis Research Center UCLA School of Medicine, California USA. Access June 19, 2008.

8. Suryohudoyo P. Dasar Molekuler Penyakit Aterosklerosis. Kapita Selekta IImu Kedokteran Molekuler. CV Sagung Seto Jakarta. 2000. 58-65.

9. Gough P.J., Gomez I.G., Wille P.T. and Raines E.W. Macrophage Expression of Active MMP-9 Induces Acute Plaque Disruption in apoE-Deficient Mice J. Clin. Invest. 2006, 116:59-69.

10. Shah P.K., Galis Z.S. Matrix Metalloproteinase Hypothesis of Plaque Rupture. Circulation. 2001, 104 : 1878.

11. Haraszthy V.I., Zambon J.J., Trevisan M., Zeid M., Genco R.J. Identification of Periodontal Pathogens in Atheromathous Plaques. J. Periodontol. 2000, 71:1554-60.

12. Stelzel M., Conrads G., Pankuweit S., Maisch B., Vogt S., Moosdorf R., Floresde-Jacoby L. Detection of Porphyromonas gingivalis DNA in Aortic Tissue by PCR. J. Periodontol. 2002, 73(8):868-70.

13. DeCarlo A.A., Winsor L.J., Bodden M.K., Harber G.J., Birkedal-Hasen B., BirkedalHasen $H$. Activation and Novel Processing of Matrix Metalloproteinases by Thiol-proteinase from the Oral Anaerobe Porphyromonas gingivalis. J. Dent Res. 1997, 76(6): 1260-1270.

14. Siscovick D.S., Lemaitre R.N., Mozaffarian D. The Fish Story: A Diet-Heart Hypothesis With Clinical Implications: n-3 Polyunsaturated Fatty Acids, Myocardial Vulnerability, and Sudden Death. Circulation. 2003, 107:2632.

15. Jung U.J., Torrejon C., Tighe A.P. and Deckelbaum R.J. n-3 Fatty acids and Cardiovascular Disease: Mechanisms Underlying Beneficial Effects. Am J Clin Nutr. 2008, 87(6): 2003S-2009S.

16. De Caterina R., Liao J.K, Libby P. Fatty Acids Modulation of Endotelial Activation. Am J Clin Nutr 2000, 71 (suppl 1): $\$ 213-23$. 
17. Mozaffarian D., Ascherio A., Hu F.B., Stampfer M.J., Willett W.C., Siscovick D.S., Rimm E.B. Interplay Between Different Polyunsaturated Fatty Acids and Risk of Coronary Heart Disease in Men. Circulation. 2005, 111: 157-164.

18. Surette M.E. The Science Behind Dietary Omega-3 Fatty Acids. CMAJ. 2008, 178 (2).

19. Anonim. Essential Fatty Acids. https://biochemianzunited.wordpress.co $\mathrm{m} /$ tag/lipids-essentialfattyacids-biology- biol1362-omega-3-omega-6 healthyfats/2016.

20. Balk E.M., Lichtenstein A.H., Chung M., Kupelnick B., Chew P., Lau J. Effect of Omega-3 Fatty Acids on Serum Marker of Cardiovascular Disease Risk: A Systemic Review. Atherosclerosis. 2006, 189: 19-30.

21. Huff M.W., Telford D.E. Dietary Fish Oil Increase The Conversion of VLDL apoB to LDL apoB. Atherosclerosis. 1989, 9: 58-66. Journal of Medical Update. 2008, 3(1) : 31-49. 